Stratigraphy of the

Morrison Formation

In Part of Northwestern

New Mexico

GEOLOGICAL SURVEY BULLETIN 1030 - J

This report concerns work done on behalf of the U.S. Atomic Energy Commission and is published with the permission of the Commission 


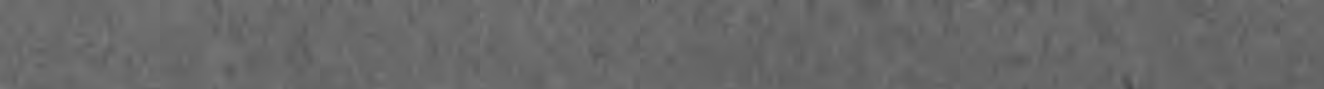

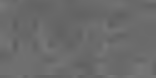

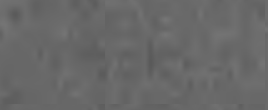

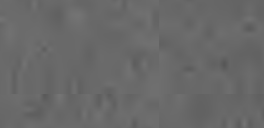

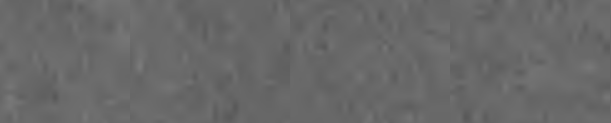

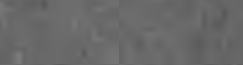

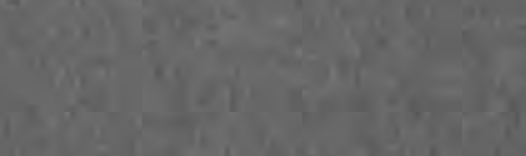
$\left(y^{+1}+1\right.$
$\operatorname{lit}_{10}$
2.

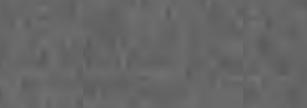

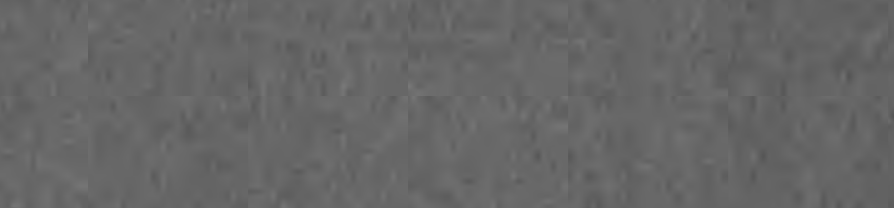

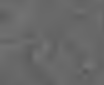

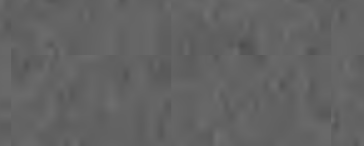 Minifing 4

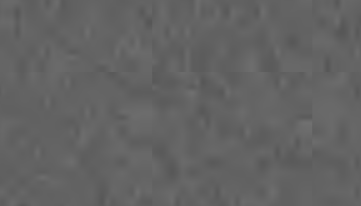

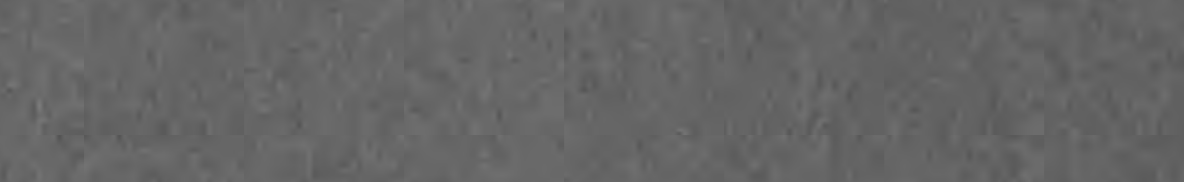
P.

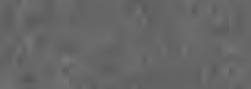

$\left.11\right|^{4}+2=$

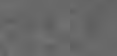

12

init: Sig

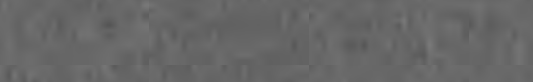

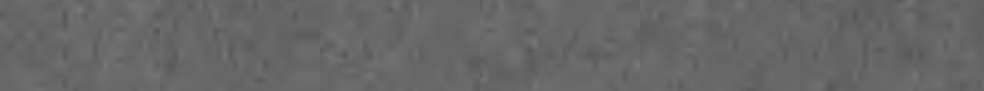

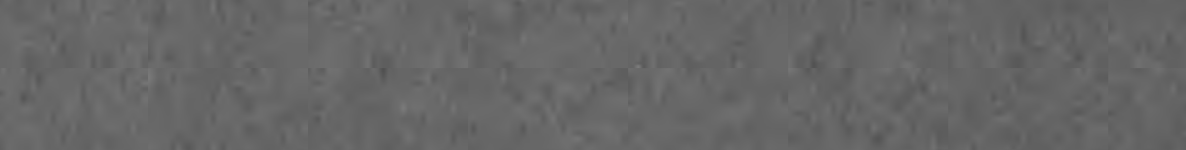

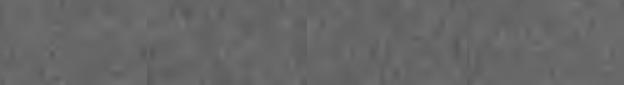

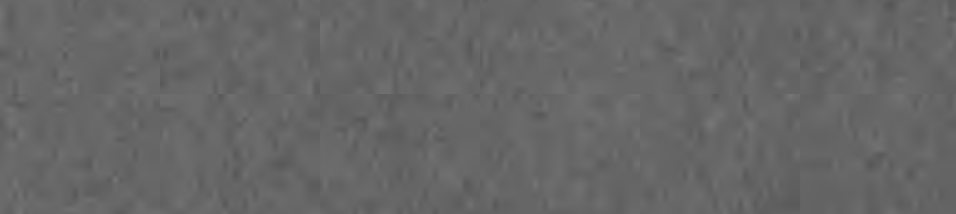 $x^{2}+4, y$

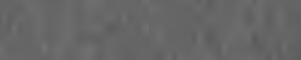
$+1+2$

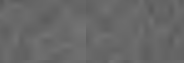
(1)

$\frac{2}{2}$

ign
d

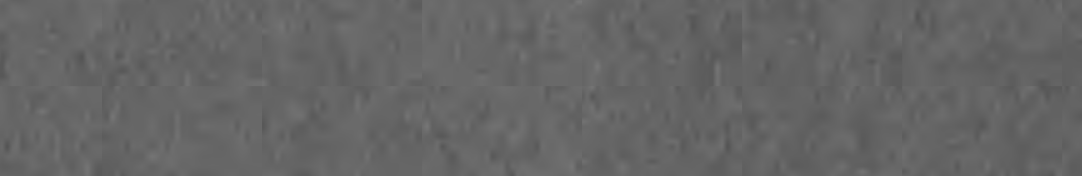

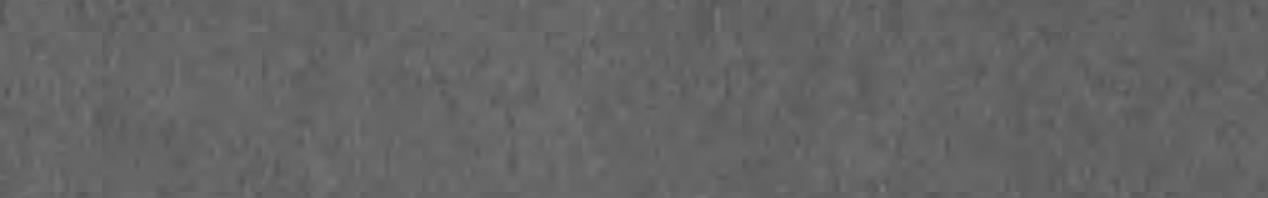

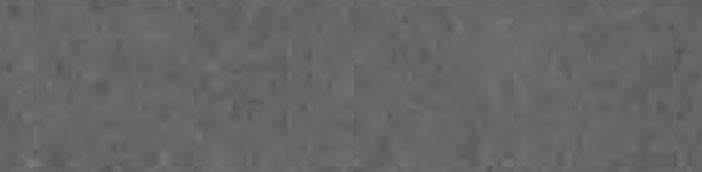

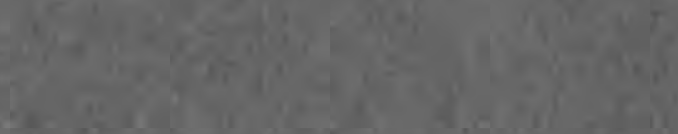

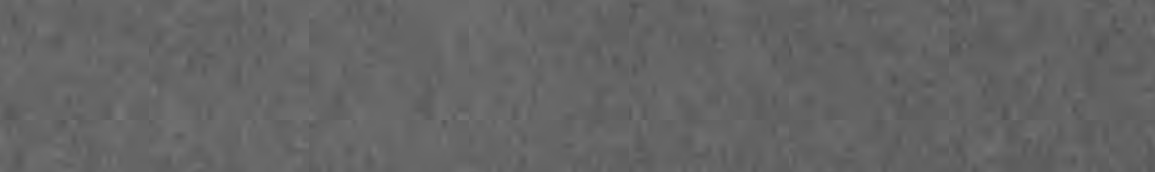

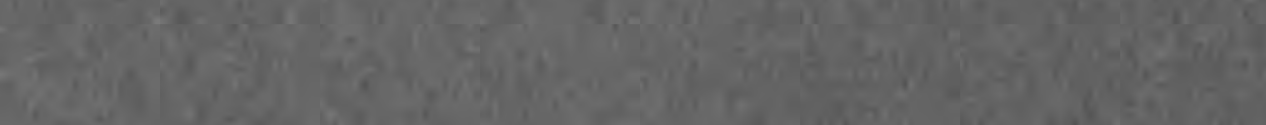

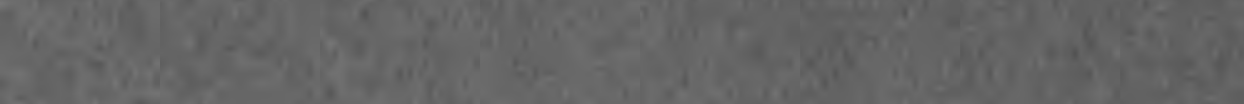

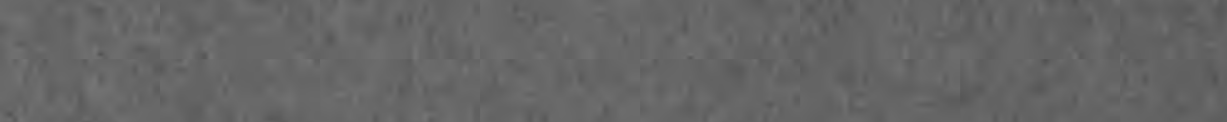

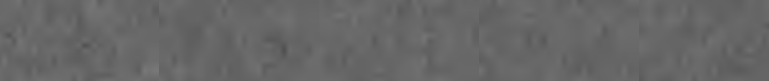 $1+\frac{1}{2}+\frac{4}{6}+7 y$

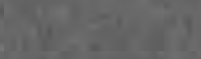

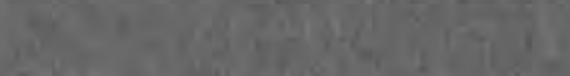




\section{Stratigraphy of the}

Morrison Formation

\section{In Part of Northwestern}

New Mexico

By V. L. FREEMAN and L. S. HILPERT

CONTRIBUTIONS TO THE GEOLOGY OF URANIUM

GE OLOGICAL S URVEY B ULLETIN $1030-\mathrm{J}$

This report concerns work done on behalf of the U.S. Atomic Energy Commission and is published with the permission of the Commission

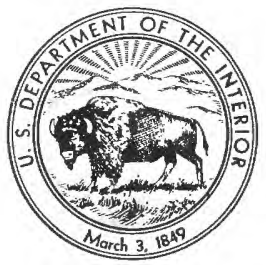


UNITED STATES DEPARTMENT OF THE INTERIOR

Fred A. Seaton, Secretary

GEOLOGIGAL SURVEY

Thomas B. Nolan, Director 


\section{CONTENTS}

Aage

Abstract

Introduction.........

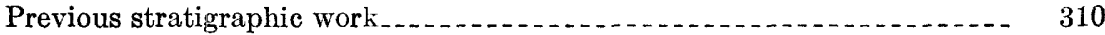

Morrison formation in northwestern New Mexico _................ 313

Recapture member..................... 313

Westwater Canyon member............... 314

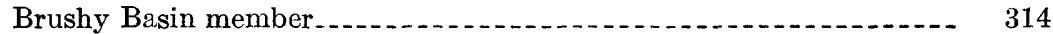

Stratigraphy of the Morrison formation near Laguna _................ 315

Conclusions

Literature cited . . . . . . . .

Stratigraphic sections of the Morrison formation .................... 320

\section{ILLUSTRRATIONS}

Figure 58. Index map of part of New Mexico

59. Nomenclature of the Morrison formation in northwestern

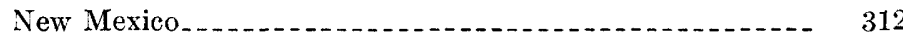

60. Nomenclature of the Morrison formation in the Laguna area_ $\quad 315$

61. Interrelationship of the members of the Morrison formation.- 316

III 



\title{
CONTRIBUTIONS TO THE GEOLOGY OF URANIUM
}

\section{STRATIGRAPHY OF THE MORRISON FORMATION IN PART OF NORTHWESTERN NEW MEXICO}

\author{
By V. L. Freeman and L. S. Hilpert
}

\begin{abstract}
In the summer of 1954 while investigating the uranium resources of northwestern New Mexico, the writers noticed that the stratigraphic nomenclature of the Morrison formation in use in the Laguna area was not consistent with that in use elsewhere in the region. A review of the literature led to the agreement that the nomenclature currently in use elsewhere in the area, such as near Grants, is satisfactory. This usage divides the Morrison formation into three members; in ascending order they are the Recapture, the Westwater Canyon, and the Brushy Basin members. These members may be recognized and have been correlated throughout northwestern New Mexico. In the Laguna area the Recapture, Westwater Canyon, and most of the Brushy Basin members, as correlated by the writers, are present in the stratigraphic interval that has previously been considered as Recapture. The sandstone previously considered as Westwater Canyon is in our opinion at the top of the Brushy Basin. This sandstone is of economic importance and is informally called the Jackpile ore-bearing bed.
\end{abstract}

\section{INTRODUCTION}

The field work on which this report is based was done during the summer of 1954 when the writers were engaged in investigating the uranium resources of northwestern New Mexico on behalf of the U. S. Atomic Energy Commission. While studying the uranium potential of the stratigraphic units, a discrepancy between the nomenclature of the Morrison formation of Late Jurassic age in the Laguna area and in other parts of northwestern New Mexico became evident. As correct correlations were a necessity in evaluating the resource potential of the stratigraphic units, a stratigraphic study was undertaken to assure proper correlations. Eleven stratigraphic sections were measured in northwestern New Mexico, four sections measured by others were examined, and a review of the literature was undertaken. This report reviews the names that have been proposed for the members of the Morrison formation in northwest New Mexico, describes them, and presents the results of the writers' work in correlating the members near Laguna with adjacent areas. The work was aided by the cooperation of the staffs of the mining companies in the area and the Atomic Energy Commission. Use was 
made of stratigraphic sections measured by L. C. Craig and T. E. Mullens of the Geological Survey.

\section{PREVIOUS STRATIGRAPHIC WORK}

The nomenclature of the formations of Jurassic age in northwestern New Mexico was summarized, and a complete bibliography of the Jurassic literature was presented, by Baker, Dane, and Reeside (1936, p. 43). This report, together with a revision by them (1947), is the standard reference on Jurassic stratigraphy in the region. In the earlier paper the Morrison formation in northwestern New Mexico included the Todilto limestone member at the base, overlain in ascending order by a sandstone member and a shale member (Baker, Dane, and Reeside, 1936, table 8). In the revision the Todilto limestone was not included in the Morrison formation (1947, p. 1668). No attempt was made in these reports to subdivide the Morrison formation above the Todilto limestone into formal members.

The first subdivision of the Morrison formation on the Colorado Plateau was made by Lupton (1941) who gave the name Salt Wash sandstone member to a basal conglomeratic sandstone unit in eastcentral Utah. At Bluff, Utah (fig. 58), a massive sandstone that forms the cliffs along the San Juan River, and locally referred to as the Bluff sandstone, was considered by Baker, Dane, and Reeside (1936, p. 21) as a member of the Morrison formation. Gregory (1938, p. 58), in the same area, recognized four members of the Morrison formation: the Bluff sandstone at the base, overlain by the Recapture shale, the Westwater Canyon sandstone, and the Brushy Basin shale.

In 1947 the Geological Survey began a study of the stratigraphy of the Morrison formation on the Colorado Plateau (Craig and others, 1955). The study resulted in the definition of the distribution of the members of the Morrison formation in the Colorado Plateau region. As this study centered on the then known uranium ore deposits in the Morrison formation in western Colorado and eastern Utah, the Morrison formation of northwestern $\mathrm{New}$ Mexico was not investigated in detail. Craig tentatively assigned the Bluff sandstone, as a formation, to the upper part of the San Rafael group but retained as members of the Morrison formation in ascending order: the Salt Wash, Recapture, Westwater Canyon, and Brushy Basin. These assignments have been accepted by the Geologic Names Committee of the Geological Survey. The Salt Wash member was shown (Craig and others, 1955 , p. 135,138 ) to extend from southeastern Utah a short distance into New Mexico, where it intertongues southwardly with. the Recapture member and is absent elsewhere in New Mexico. The remaining members of the Morrison formation, the Recapture, West- 


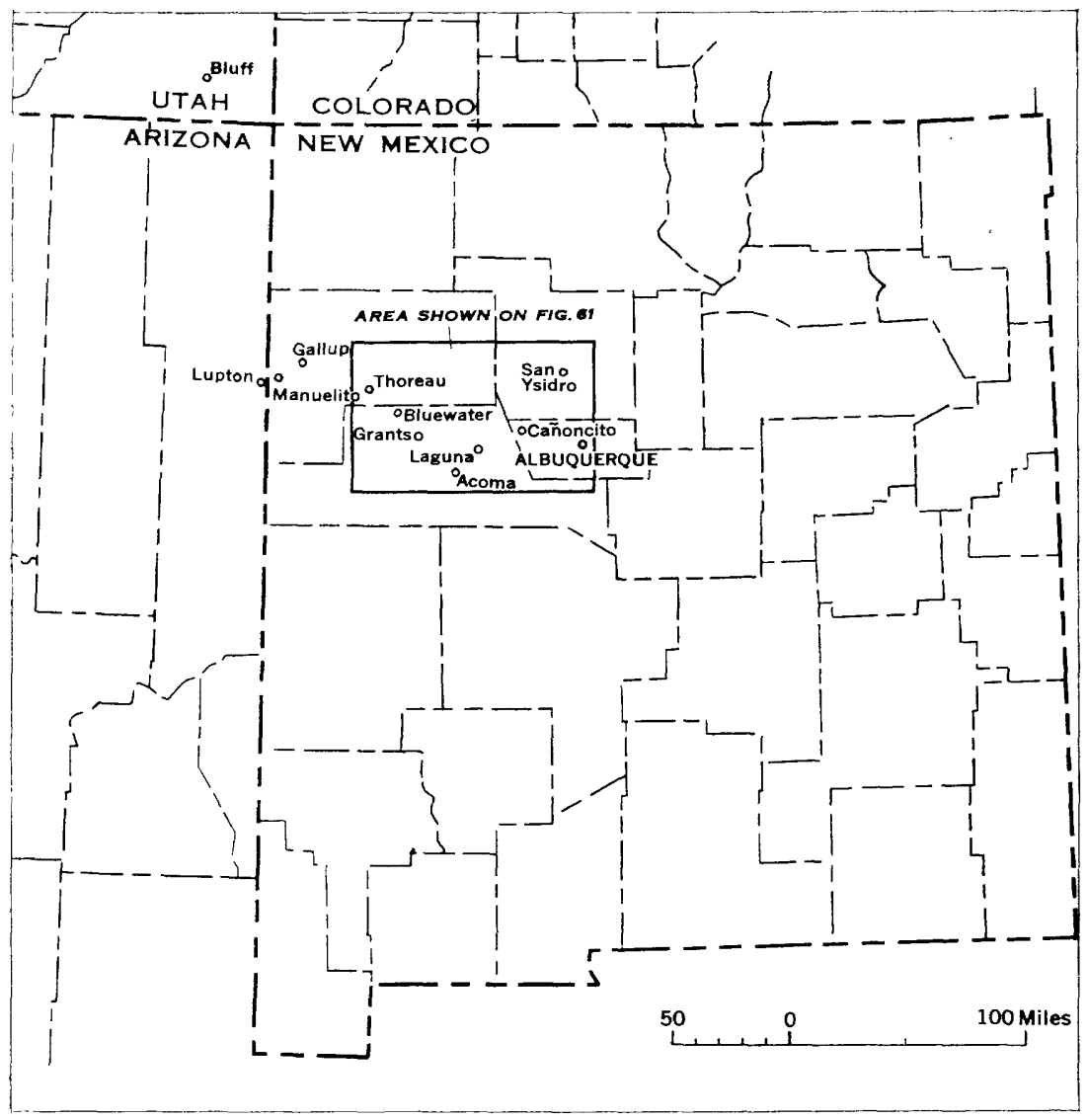

Frgune 58.- Index map of part of New Mexico and adjacent States showing localities referred to in text.

water Canyon, and Brushy Basin, were shown to extend to and beyond the Laguna area.

Before the extension of the Recapture, Westwater Canyon, and Brushy Basin members of the Morrison formation into New Mexico, a set of informal member names was suggested by Kelley and Wood (1946) and adopted by Silver (1948) in the Laguna area. These names were, in ascending order: the buff shale, the brown-buff sandstone, the white sandstone, and the variegated shale. Craig considered the buff shale to be an equivalent of the Summerville formation and the brown-buff sandstone and the white sandstone to be equivalents of the Bluff sandstone (Craig, oral communication). The variegated shale apparently contains equivalents of the Recapture, Westwater Canyon, and Brushy Basin members.

The discovery of commercial quantities of uranium ore in northwestern New Mexico in 1950, resulted in a study of the sedimentary 
rocks of Jurassic age by the Atomic Energy Commission (Rapaport, Hadfield, and Olsen, 1952). The geologists of the Atomic Energy Commission recognized the presence of the Summerville formation and Bluff sandstone in the area of northwestern New Mexico east of Gallup (Rapaport, Hadfield, and Olsen, 1952, p. 20) and followed Craig's (Craig and others, 1955) terminology for the Morrison formation (fig. 59). This terminology has been widely accepted by the mining companies.

Smith $(1951$, p. $13 ; 1954$, p. 15$)$ recently proposed a partly new set of names for the members of the Morrison formation (fig. 59). In the area near Thoreau, N. Mex., he divides the Morrison formation into the Chavez at the base, stating that it may be equivalent to the Recapture; an overlying Prewitt sandstone member, equivalent to the Westwater Canyon; and the Brushy Basin at the top. The writers believe that the similarity of the members of the Morrison in the

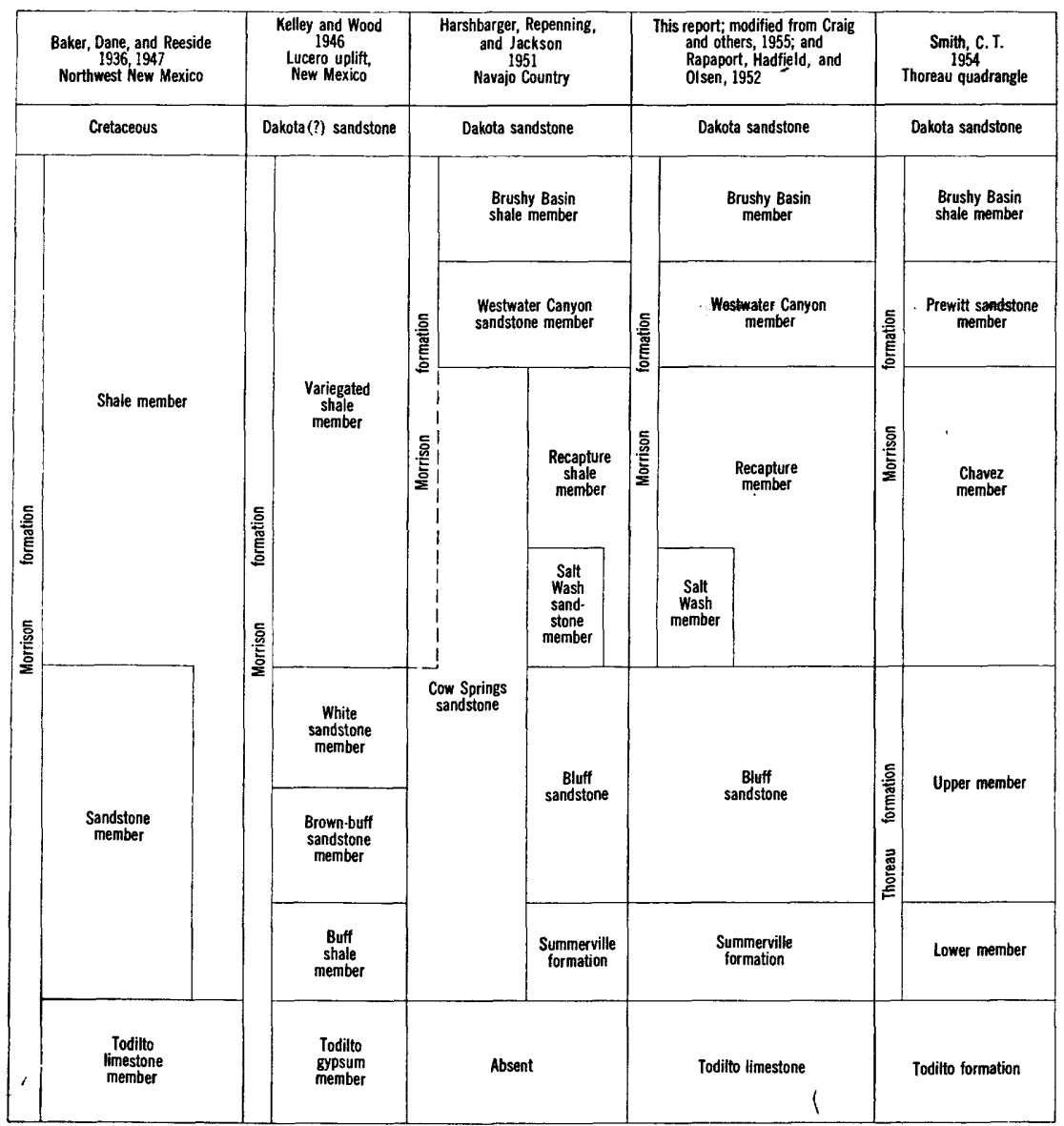

Figure 59.-Nomenclature of the Morrison formation in northwestern New Mexico. 
Thoreau-Grants area with those in southeast Utah could only be possible if they are continuous beneath the San Juan Basin. It, therefore, seems desirable to use the same terminology, especially as it is in general use by the mining companies in northwest New Mexico, rather than adopt the new terminology of Smith. In summary, the Morrison formation throughout most of northwestern New Mexico is considered to consist of the Recapture at the base, the Westwater Canyon, and the Brushy Basin. A summary of the terminology is presented in figure 59.

\section{MORRISON FORMATION IN NORTHWESTERN NEW MEXICO}

In the belt of outcrop of the Jurassic rocks between Gallup and Albuquerque, the Morrison formation as used here consists of three conformable members: the Recapture, Westwater Canyon, and the Brushy Basin. To the west, on the Navajo Indian reservation, several upper Jurassic units grade into a sand facies that has been named the Cow Springs sandstone (Harshbarger, Repenning, and Jackson, 1951). At Lupton, Ariz., the Recapture and Westwater Canyon members of the Morrison are recognizable although with difficulty. Farther to the south the Recapture grades into the Cow Springs sandstone leaving only the Westwater Canyon as a recognizable member of the Morrison formation because the Brushy Basin is missing, probably due to preDakota erosion. About 3 miles east of Gallup where the Jurassic section crops out on the flank of the Zuni uplift, the Recapture is recognizable although it is very sandy. A few miles farther east the Brushy Basin appears beneath the Dakota sandstone of Cretaceous age, and in the area of this report the Morrison formation consists of the three members listed above.

\section{RECAPTURE MEMBER}

The Recapture member in the Gallup-Albuquerque area ranges from about 20 to about 170 feet in thickness, in general thinning southward. It consists largely of grayish-red sandy claystone and clayey sandstone with limy nodules and white, clean, fine- to mediumgrained sandstone in alternating units 5 to 10 feet in thickness. The clean sandstone beds are most common in the western part of the area and probably represent tongues of the Cow Springs sandstone. Clayey sandstone is the dominant rock type in the eastern and southern parts of the area. The Recapture in most of the area is conformable with the underlying Bluff sandstone, but to the north near San Ysidro it rests directly upon the Summerville formation. In general the upper part of the usually clean Bluff sandstone is clayey, but the contact with grayish-red clayey sandstone of the overlying Recapture $402655-56-2$ 
is sharply marked. In the Laguna area the Recapture interfingers with the Bluff sandstone. On Haystack Butte, near Bluewater, the basal unit of the Recapture member is a conglomeratic sandstone that rests on a slightly channeled surface cut into the Bluff sandstone; they are distinguished by grain size and type of crossbedding.

The Recapture generally is overlain by the Westwater Canyon from which it is easily distinguished. A few miles south of Laguna the Recapture is composed of clayey sandstone beds that, because of the absence of the Westwater Canyon, are directly overlain by Brushy Basin strata of similar lithology. Near Acoma, farther to the southwest, the two members could not be separated with certainty.

\section{WESTWATER CANYON MEMBER}

The Westwater Canyon member ranges from about 50 to 190 feet in thickness in the Gallup-Albuquerque area, except near Laguna where it is locally absent. In general, the Westwater Canyon thickens from the Laguna area toward Gallup to the west and toward San Ysidro to the north. The Westwater Canyon is a yellowish-gray to light-grayish-red, locally conglomeratic, fine- to coarse-grained sandstone that is characterized by scour-and-fill crossbedding and by angular grains of unweathered feldspar. Discontinuous lenses of grayish-green sandy claystone are present. The Westwater Canyon interfingers with the underlying Recapture and the overlying Brushy Basin members.

\section{BRUSHY BASIN MEMBER}

The thickness of the Brushy Basin member is largely determined by the amount of deformation and erosion before deposition of the Dakota sandstone. The details of the pre-Dakota deformation are not known, but, in general, it consisted of northeastward tilting and local broad folding. Subsequent erosion resulted in a southwestward irregular thinning of the Brushy Basin. In northwestern New Mexico the member ranges in thickness from a knife edge to about 370 feet. The Brushy Basin consists of partly variegated but dominantly light greenish-gray, slightly swelling, locally sandy claystone containing limy nodules. Thick sandstone units lithologically similar to the Westwater Canyon, thin hard green sandstone beds, and thin clayey limestone beds are rare to common in occurrence. Pinkish-orange jasper commonly occurs, especially near the base, as crack fillings and as cement in thin sandstones. As the Brushy Basin and the Westwater Canyon members interfinger, the contact between the members may be difficult to determine. The writers placed the contact at the base of the lowest recognizable claystone in the Brushy Basin and acknowledge that some of the sandstone beds placed in the Brushy Basin may laterally be equivalent to the Westwater Canyon member. 


\section{STRATIGRAPHY OF THE MORRISON FORMATION NEAR LAGUNA}

The Morrison formation in the Laguna area became of economic importance with the discovery of uranium in 1951. As a consequence, a great deal of geologic work is in progress in the area. The nomenclature of the Morrison formation in general use is that used in this report, but it is not being applied to the same stratigraphic units. Figure 60 compares the terminology in previous use with that proposed

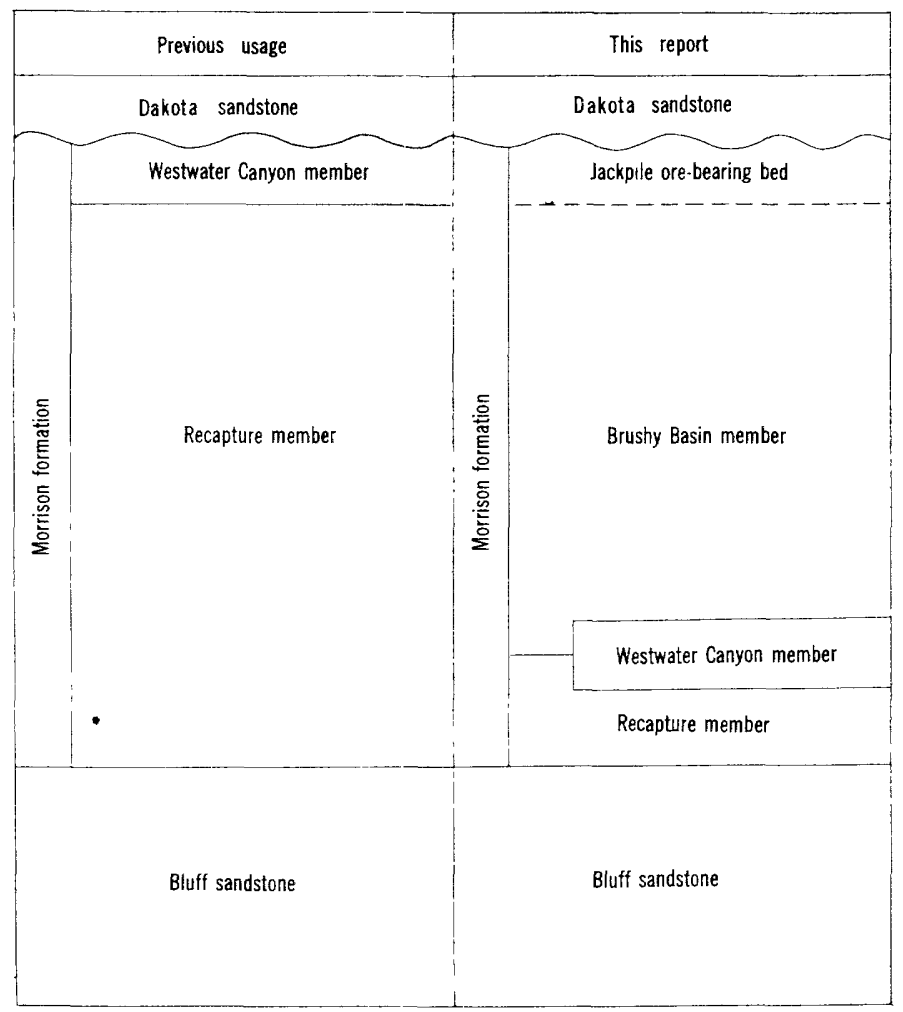

Figure 60.-Nomenclature of the Morrison formation in the Laguna area, New Mexico.

now. The correlation of the members of the Morrison formation between Laguna and adjacent areas is difficult because of: the similarity of the ore-bearing sandstone unit, informally called Jackpile ore-bearing bed in this report, with the Westwater Canyon member; the local absence of the Westwater Canyon; the unusual thickness of the Brushy Basin member; and the thinness and incomplete exposures of the Recapture member. The Salt wash member is not present in this area. 
Figure 61 shows the location of some of the measured sections studied and the relationship of the members of the Morrison between the sections. The sections used are presented following page 319 . The Haystack Butte and Red Bluff sections are in the Grants area where there is general agreement on the nomenclature: At Haystack Butte the contact between the Westwater Canyon and the Brushy Basin is placed at the base of the lowest persistent claystone unit. Ledges of sandstone that could not be distinguished from the Westwater Canyon are present throughout the entire thickness of the Brushy Basin. Eastward toward the Red Bluff section the Westwater Canyon interfingers with the Brushy Basin and to a lesser extent with the Recapture, resulting in a considerable thinning of the West-

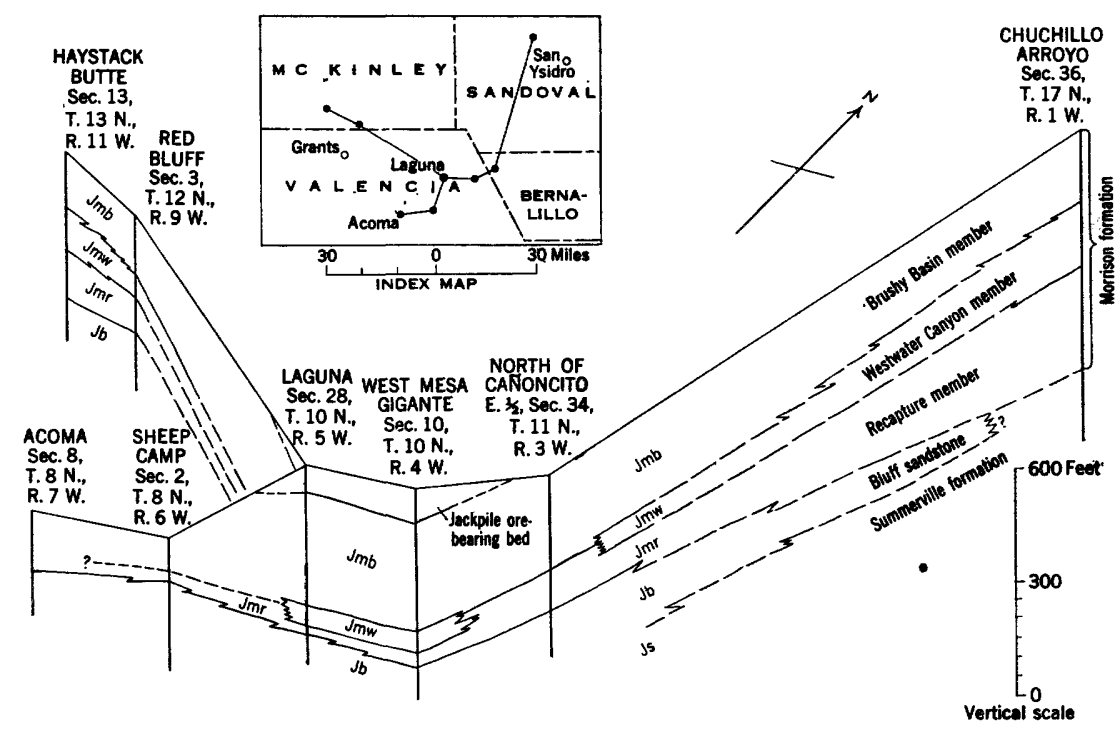

Figure 61.-Interrelationship of the members of the Morrison formation.

water Canyon. Interfingering of the Recapture with the Bluff sandstone was not seen but may be present and may account for some thinning of the Recapture. The Morrison formation is not exposed in the area between the Red Bluff and Laguna sections.

At the Laguna section, only the uppermost 29 feet of the Bluff sandstone is exposed. It is overlain by about 20 feet of reddishbrown and minor greenish-gray, very clayey sandstone with limy nodules that is typical of the Recapture member. Above the slope formed on the Recapture is a prominent ledge, about 55 feet thick, of the Westwater Canyon member. As no exposures of the Recapture exist between the Red Bluff and Laguna section, the manner of its thinning is not known. Silver (1948) showed that in this area the 
entire Jurassic section thins southward by overlap against a Jurassic highland, and the writers believe the thinning of the Recapture is probably due to the same cause.

The Westwater Canyon is similar lithologically at the Laguna section and in the southeastern Utah area. It contains angular grains of unaltered feldspar, is moderately to poorly sorted, medium grained to coarse grained, and is scour-and-fill crossbedded. These features are in marked contrast to the dominantly well-sorted, fine-grained, and sweeping crossbedded Bluff sandstone that is not known to contain the angular grains of unaltered feldspar. South of Laguna the Westwater Canyon is not present; it probably disappears by interfingering with the Recapture and Brushy Basin members.

At the Laguna section the Brushy Basin member is about 370 feet thick. It consists of grayish-green, slightly swelling, clay-rich beds with some pinkish variegations near the base and lenticular sandstone units lithologically similar to the Westwater Canyon. The Brushy basin in the Laguna area is similar to the Brushy Basin in the Grants area and in southeastern Utah but distinctly different from the Recapture member in these areas. At the Laguna section the uppermost 65 feet of the Brushy Basin is the so-called Jackpile ore-bearing bed. It is a very pale orange and locally white sandstone that is dominantly fine grained to medium grained with minor coarse grains at the base. Feldspar grains, as well as specks of a white clay mineral, probably kaolin, are present. The sandstone is characterized by scourand-fill crossbedding, but some parallel bedding, often marked by claystone partings, is present also.

Toward Acoma, beyond the limit of the Westwater Canyon member, the Recapture and Brushy Basin members are considerably thinner (fig. 61). The contact of the Recapture and Brushy Basin can be placed with reasonable certainty as far southwest as the Sheep Camp section (fig. 61), but farther to the southwest the contact is indistinct. The Brushy Basin becomes more variegated, grayish-red colors are prevalent, and it is similar to the Recapture. At the Acoma section a reddish zone at the base of the Morrison may correlate with the Recapture, but this zone is gradational with the upper part of the formation which also contains thin reddish zones.

The West Mesa Gigante section is similar to the Laguna section; but, proceeding from the section southward along the west side of Mesa Gigante the Westwater Canyon disappears in a few miles. It reappears for about a half a mile along the south face of the meisa where it has a thickness of 58 feet; it does not reappear again until about 3 miles north of Cañoncito along the east face of the mesa where it is 47 feet thick. At this locality, S1/2 sec. $27, T .11$ N., R. $3 \mathrm{~W}$., the pinching out of the Westwater Canyon is well exposed. In 
a distance of about 50 feet along the outcrop, the entire member, consisting of 47 feet of sandstone disappears by interfingering with sandy claystone beds similar to the Recapture and Brushy Basin (fig. 61). North of the Cañoncito section, less than half a mile from the disappearance of the Westwater Canyon, the Recapture includes several sandstone beds similar to those in the Westwater Canyon.

Between the Cañoncito area and the Cuchillo Arroyo section, only the upper part of the Morrison is exposed locally. At Cuchillo Arroyo 170 feet of the Westwater Canyon is well exposed in a vertical cliff. It interfingers at top and base with the Brushy Basin and Recapture, respectively. The Recapture rests directly upon the Summerville formation from which it is distinguished with difficulty. The manner in which the Bluff sandstone has disappeared is not known, but as the Bluff has been seen by the writers to interfinger with both the Recapture member and the Summerville formation, a gradual thinning by interfingering with these units is at least partly responsible.

\section{CONCLUSIONS}

The Morrison formation in the area of Laguna, N. Mex., consists of a 20-foot unit at the base assigned to the Recapture, a 55-foot sandstone assigned to the Westwater Canyon, and a 370-foot unit assigned to the Brushy Basin. The upper 65 feet of the Brushy Basin is a sandstone that has been considered by others as the Westwater Canyon to which it is lithologically similar; the entire underlying Morrison, in consequence, was considered as Recapture. The members of the Morrison formation near Laguna are lithologically similar to the members in the area near Grants, where there is general agreement of nomenclature, and in the San Ysidro area, where they are so typical as to preclude disagreement. The Recapture and the Westwater Canyon, however, are thinner near Laguna because of proximity to the edge of their areas of deposition; and the Brushy Basin is much thicker, probably because of less removal before deposition of the Dakota sandstone.

The sandstone occupying the uppermost part of the Brushy Basin member has been traced from the Laguna section, in nearly continuous exposures, into the ore-bearing sandstone at the Jackpile mine of the Anaconda Copper Mining Co. It ranges in thickness from a knife edge, where cut out by pre-Dakota(?) erosion, to about 175 feet at the Jackpile mine. Because of the economic importance of this sandstone bed, it has been informally named the Jackpile ore-bearing bed of the Brushy Basin member. 


\section{LITERATURE CITED}

Baker, A. A., Dane, C. H., and Reeside, J. B., Jr., 1936, Correlation of the Jurassic formations of parts of Utah, Arizona, New Mexico, and Colorado: U. S. Geol. Survey Prof. Paper 183.

1947, Revised correlation of Jurassic formations of parts of Utah, Arizona, New Mexico, and Colorado: Am. Assoc. Petroleum Geologists Bull., v. 31, p. 1664-1668.

Craig, L. C., and others, 1955, Stratigraphy of the Morrison and related formations, Colorado Plateau region, a preliminary report: U. S. Geol. Survey Bull. 1009-E.

Gregory, H. E., 1938, The San Juan country, a geographic and geologic reconnaissance of southeastern Utah: U. S. Geol. Survey Prof. Paper 188.

Harshbarger, J. W., Repenning, C. A., and Jackson, R. L., 1951, Jurassic stratigraphy of the Navajo country: N. Mex. Geol. Soc. Guidebook, 2d field conf., p. 95-99.

Kelley, V. C., and Wood, G. H., 1946, Lucero uplift, Valencia, Socorro, and Bernalillo Counties, N. Mex.: U. S. Geol. Survey Oil and Gas Inv. Prelim. Map 47.

Lupton, C. T., 1914, Oil and gas near Green River, Grand County, Utah: U. S. Geol. Survey Bull. 541-D.

Rapaport, Irving, Hadfield, J. P., and Olsen, R. H., 1952, Jurassic rocks of the Zuni uplift, New Mexico: U. S. Atomic Energy Comm., Tech. Inf. Service, RMO-642.

Silver, Caswell, 1948, Jurassic overlap in western New Mexico: Am. Assoc. Petroleum Geologists Bull., v. 32, p. 68-81.

Smith, C. T., 1951, Generalized nomenclature chart for formation and member names used in road logs: N. Mex. Geol. Soc. Guidebook, 2d field conf., p. 13.

1954, Geology of the Thoreau Quadrangle, McKinley and Val
Counties, N. Mex.: N. Mex. Bur. Mines and Min. Res., Bull. 31 . 


\title{
STRATIGRAPHIC SECTIONS OF THE MORRISON FORMATION
}

\author{
VALENCIA COUNTY
}

\author{
Laguna section, NW1/4 sec. 28, T. 10 N., R. 5 W. \\ [Measured by L. C. Craig, V. L. Freeman, and T. E. Mullins]
}

Top of measured section.

Feet

Dakota sandstone:

Sandstone, white $(N 9)^{1}$, to very pale orange (10YR 8/2), weathering grayish-orange $(10 Y R 7 / 4)$, fine- to medium-grained, well-sorted; composed of subrounded to rounded clear quartz with rare white accessory grains; well-cemented, calcareous; subparallel laminations filling shallow erosion troughs, thin- to medium-bedded, some ripple laminations. Conglomeratic sandstone near base, pebbles of gray and black chert, pebbles subangular to subrounded. Abundant plant impressions; some carbonaceous material. Unit forms vertical cliff.

Morrison formation:

Brushy Basin member:

Sandstone, very pale orange $(10 Y R 8 / 2)$, locally white $(N 9)$ in upper part, predominantly fine- to medium-grained with rare coarse grains at base, well-sorted; composed of subangular to subrounded clear quartz with abundant pink feldspar grains and much interstitial kaolin; coarse grains are quartz, feldspar, granite, and rare red and brown chert; moderately well cemented; channeling with subparallel laminations filling erosion troughs; minor clay partings; unit forms ledgy slope with upper 16 feet forming a vertical cliff. (Jackpile ore-bearing bed)

Claystone, grayish-red $(10 R 4 / 2)$ and light greenish-gray (5GY 8/1), very sandy (to fine-grained); earthy weathering; slightly fissile; forms banded slope . . . . . .

Sandstone, very pale orange $(10 Y R 8 / 2)$ to yellowish-gray $(5 Y 8 / 1)$, medium- to coarse-grained, moderately sorted; composed of subrounded to rounded clear quartz with abundant pink and white accessory grains; friable, weakly cemented; bedding not visible; forms steep slope......

Claystone, grayish-red (10 $R 4 / 2)$, very sandy (to fine-grained); earthy weathering; slightly fissile

Sandstone, with claystone and limestone near top; sandstone grayishyellow (5Y 8/4) to white $(N 9)$, medium-grained with some very coarse grains at top, moderately sorted; composed of subrounded quartz with common pink and white accessory grains; very coarse grains at top are predominantly clear to white quartz, pink feldspar, and granite; well-cemented to friable; cross-laminations filling erosion troughis. Eight-foot claystone and limestone unit below 10-foot top ledge same as in unit below. Unit forms ledgy to rounded slope.

1 The colors and color numbers are from the Rock-color chart of the National Research Council, Washington, D. C., 1948. 
Claystone, (90 percent) and limestone (10 percent). Claystone, dominantly light greenish-gray $(5 G Y 8 / 1)$, with some yellowishgray $(5 Y 8 / 1)$ and at base pale-red $(5 R 4 / 2)$ to grayish-red (10R $4 / 2$ ), silty to sandy (fine-grained). Limestone, very light gray $(N 8)$, weathers white $(N 9)$, dense to finely crystalline. Unit weathers to steep rubble-covered slope.....................

Sandstone, conglomeratic, very pale orange $(10 Y R 8 / 2)$ to yellowishgray $(5 Y 8 / 1)$ very fine- to coarse-grained, poorly sorted; composed of subangular and subrounded clear quartz with abundant pink feldspar and uncommon white and green accessory grains. Conglomerate consists mainly of tan, brown, gray, and red chert pebbles and granules averaging $3 / 4$ inch with maximum $1 \frac{1}{2}$ inches in diameter, and abundant pink feldspar and white to clear quartz grains averaging $1 / 8$ inch with maximum $1 / 2$ inch in diameter; crosslaminations filling erosion troughs; locally forms prominent ledge.

Coarser material concentrated at base of unit . . . . . . . . .

Claystone (85 percent), sandstone (10 percent), and limestone ( 5 percent). Claystone, yellowish-gray (5Y 8/1) to light greenish-gray (5G 8/1) and yellowish-gray ( $5 Y 7 / 2$ ), slightly silty to slightly sandy (to fine-grained); frothy weathering, forms pastel green and pink slope. Sandstone, light greenish-gray ( $5 G 8 / 1)$ to very light gray (N8), very fine grained; forms beds as much as 2 feet thick, bedding not visible; weathers to slabby ledges. Limestone, very light gray (N8), dense; forms nodular beds to hackly ledges 1 foot thick. Pink bands in claystone due to formation of pink cherty spots

Sandstone (65 percent) and claystone (35 percent). Sandstone, yellowish-gray ( $5 Y$ 8/1), fine- to medium-grained, moderately sorted; composed of subangular to subrounded clear quartz with common red, green, and white accessory grains; well-cemented with coarse crystals of calcite; unit is lenticular, beds 1 to 5 feet thick of wavy laminations and cross-laminations filling erosion troughs. Weathers to prominent ledges. Claystone, very light gray (N8), sandy (very fine- to fine-grained); hackly to earthy weathering, forms narrow slopes between ledges. Locally the sandstone contains dinosaur bones, gastroliths, and stringers of granule to pebble size reddish-brown subangular chert

Claystone (70 percent), sandstone (15 percent), and limestone (15 percent). Claystone, variegated, dominantly yellowish-gray (5Y $8 / 1$ ), to light greenish-gray ( $5 G Y 8 / 1$ ) containing thin beds of grayish-purple $(5 P 4 / 2)$ and grayish-red purple $(5 R P 4 / 2)$ near the base, sandy; in part calcareous; frothy weathering. Sandstone, yellowish-gray ( $5 Y 8 / 1$ ), fine- to very fine-grained, well-sorted; composed of subangular clear quartz with abundant pink and white and uncommon green accessory grains (pink probably feldspar); forms lenticular beds 1 to 10 feet thick pinching out laterally within 300 feet, cross-laminations filling erosion troughs. Limestone, very light gray $(N 8)$, weathers white $(N 9)$; forms hackly to concre-

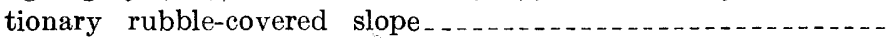


Westwater Canyon member:

Sandstone, yellowish-gray (5Y 7/2) to grayish-yellow (5Y 8/4), mediumto coarse-grained with rare grains as much as one-eighth inch in diameter, poorly sorted; composed of subangular clear quartz with common pink feldspar, uncommon red and white accessory grains; firmly cemented, calcareous; medium scale wedging crosslaminations; forms prominent cliff above ledgy slope below. A lenticular bed at base is 1 foot thick, containing pebbles of red and gray chert and limy claystone. Limonite staining common-

Total Westwater Canyon member

Recapture member:

Sandstone, clayey, and claystone, sandy, reddish-brown (10R 3/4) and greenish-gray ( $5 G Y 7 / 1$ ), fine- to medium-grained, poorly sorted; composed of subrounded stained quartz with uncommon orange and black accessory grains; calcareous; locally stained with limonite. At top of unit is zone of large ( 1 foot) nodules of radiating calcite.

Total Recapture member.

Total Morrison formation

Bluff sandstone (part):

Sandstone, clayey, grayish-yellow (5Y 8/4) to light greenish-gray (5GY 8/1), medium-grained, fair sorting; composed of subrounded grains of quartz with uncommon black and orange accessory grains; calcareous; bedding obscure. Becomes increasingly clayey upward. Limonite staining common. Weathers to

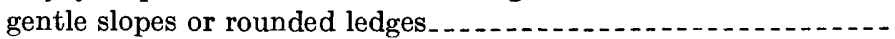
Base of measured section.

\section{VALENCIA COUNTY}

Acoma section, $\mathrm{NW}^{1 / 4}$ sec. $8, \mathrm{~T} .8 \mathrm{~N}, \mathrm{R} .7 \mathrm{~W}$.

[Measured by V. L. Freeman, November 1954]

Dakota sandstone:

Not measured or described.

Top of section.

Morrison formation:

Sandstone, clayey, dusky red ( $5 R 3 / 4)$ (30 percent) and light greenishgray ( $5 G Y$ 8/1) (70 percent), gypsiferous, some limy nodules present. Unit contains minor sandstone beds like unit below. Unit forms slightly frothy surface.

Sandstone, yellowish-gray (5Y 8/1), medium- to fine-grained, wellsorted, subrounded, grains of quartz with uncommon red and orange accessory grains; friable, calcareous; very lenticular beds with minor beds of argillaceous sandstone like below except entirely dusky red; crossbedding is contorted low angle and medium scale, filling scour features . . . . . . . . . . . . . .

Sandstone, clayey, like top unit but 25 percent dusky red and 75 cent light greenish-gray 
Sandstone, white (N9), medium- to coarse-grained, conglomeratic, poorly sorted, grains of quartz with orange, red, and gray accessory grains, pebbles to one-half inch are of chert and clay (chert is mostly red with gray and green present); slightly friable, calcareous; crossbedding is low angle and medium scale, filling scour features

Sandstone, clayey, dusky red $(5 R 3 / 4)$ and light greenish-gray $(5 G Y 8 / 1)$ in about equal amounts, fine-grained, poorly sorted, some limy nodules, minor amounts of sandy claystone and sandstone like below, forms slightly frothy surface .............

Sandstone, yellowish-gray (5Y 8/1), medium-grained, well-sorted, subrounded, grains of quartz with uncommon red and orange accessory grains; friable, calcareous; very lenticular beds with some argillaceous sandstone like below near center of unit; contorted crossbedding is low angle and medium scale, filling

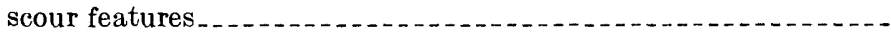

Sandstone, clayey, dusky red $(5 R 3 / 4)$, fine-grained, poorly sorted; forms slightly frothy surface.

NotE.-At least lowest unit is probably equivalent to Recapture member

Total Morrison formation

Bluff sandstone (part):

Sandstone, pale yellowish-green ( $10 G Y$ 8/2), fine-grained, well-sorted, subrounded grains of quartz with rare orange and red accessory grains; friable, some calcareous cement, some unknown white cement; unit weathers into rounded knobs; bedding not visible

Not measured

Base of section.

\section{SANDOVAL COUNTY}

Cuchillo arroyo section, sec. 36 , T. 17 N., R. 1 W.

[Measured by L. C. Craig and V. L. Freeman, 1950]

Top of measured section.

Morrison formation (part):

Brushy Basin member (part):

Feet

Sandstone, very pale orange (10YR 8/2), fine-grained, subangular, grains of clear quartz with uncommon orange and black accessory grains; hard, siliceous cement; lenticular strata, forms prominent local capping ledge

.


Brushy Basin member (part)-Continued

Claystone, light greenish-gray $(5 G 8 / 1)$ to light-gray (N7) with minor pale reddish-brown $(10 R 5 / 4)$ and pale yellowish-brown (10YR $4 / 2$ ) at top, silty to very fine grained sandy; weathers to earthy light greenish-gray slope with a few pale reddish-brown bands at top; one 6-inch lens of pale reddish-brown silicified claystone or

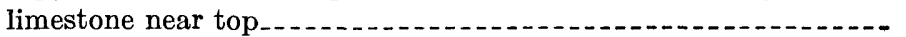

Total measured Brushy Basin member

Total Brushy Basin member ${ }^{2}$

Westwater Canyon member:

Sandstone, light olive-gray $(5 Y 5 / 2)$ to yellowish-gray $(5 Y 8 / 1)$ to light greenish-gray ( $5 G Y 8 / 1$ ), very fine-grained at top and coarsegrained at bottom, predominantly medium-grained, subangular to subrounded, grains of clear quartz with rare orange and black accessory grains; medium-scale cross laminated, scour bedding.

Note.-Top four Westwater sandstone units appear transitional to Brushy Basin member.

Claystone, pale grayish-yellow (5Y9/4) to pale greenish-gray $(5 G 6 / 1)$, slightly silty to medium-grained sandy; weathers to earthy slope

Sandstone, grayish-orange (10YR 7/4) to yellowish-gray $(5 Y 8 / 1)$, very fine-grained to medium-grained, subangular to rounded, poorly sorted, grains of clear quartz with rare orange and gray to black accessory grains; weakly cemented with streaks and bands of firm calcareous cement; medium-scale cross lamination indicated, scour bedding; forms ledgy slope

Claystone, greenish-gray ( $5 G Y 6 / 1)$, silty to slightly fine-grained sandy; weathers to earthy sandy slope, abundant very light gray (N8) dense to very fine-grained limestone nodules on surface...-

Sandstone, pale yellowish-orange $(10 Y R \quad 8 / 6)$ to yellowish-gray (5Y 8/1) to white, fine- to medium-grained, subangular to subrounded, moderately sorted, grains of clear quartz with uncommon orange and white accessory grains, locally has specks of unknown white cement; medium-scale cross-laminated, channeling; lateral to section contains thin lenses of greenish claystone. . . . . . . .

Claystone, grayish-red $(10 R \quad 4 / 2)$ and light greenish-gray $(5 G 8 / 1)$ with minor very fine- to fine-grained sandstone lenses..........

Sandstone, pale yellowish-orange $(10 Y R \quad 8 / 6)$ to yellowish-gray (5Y 8/1) to white (N9), fine- to medium-grained, subangullar to subrounded, moderately sorted, grains of clear quartz with uncommon orange and white accessory grains, locally has specks of unknown white cement; medium-scale cross-laminated, channeling

Total Westwater Canyon member

2 Measured by E. H. Baltz, Jr., oral communication. 
Recapture member:

Feet

Claystone, and sandstone (20 percent). Claystone, very dusky red $(10 R 2 / 2)$, silty to slightly fine-grained sandy, structure partly masked, some thin irregular parallel beds; sandstone, light greenish-gray ( $5 G Y 8 / 1)$ to yellowish-gray (5Y 8/1), fine-grained, subangular,' moderately to poorly sorted, some interstitial clay, grains of clear quartz with uncommon orange and black and minor green accessory grains; in structureless beds 6 inches to 3.5 feet thick; unit forms steep earthy slopes except under overly-

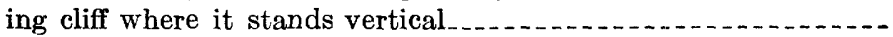

Sandstone and claystone, grayish-orange pink (10R 8/2) and very minor greenish-gray $(5 G Y 6 / 1)$, fine- to medium-grained, subangular to rounded, moderately sorted, grains of clear quartz with abundant orange and black and rare green accessory grains; medium-scale cross-lamination is indistinct; claystone, very dusky red $(10 R 2 / 2)$ to grayish-red $(10 R 4 / 2)$, silty to slightly sandy, structureless to thin parallel bedded; unit weathers to steep ledgy slope of white and yellowish gray with grayish-red bands

Sandstone, and claystone (25 percent). Sandstone, grayish-orange pink $(10 R 8 / 2)$, very fine- to medium-grained, moderately sorted, subangular to subrounded, grains of clear quartz with common black and orange accessory grains; several biotite flakes noted; medium-scale cross-laminations indistinct, local channeling; claystone, very dusky red $(10 R 2 / 2)$ to grayish-red (10R 4/2), very slightly sandy up to fine-grained, finely micaceous, contains some thin sandstone beds, light greenish-gray $(5 G Y$ 8/1) to grayish-red $(10 R 4 / 2)$, very fine- to fine-grained, subangular, moderately sorted, grains of clear quartz with abundant orange and black accessory grains; structureless; unit as whole weathers to pale-red and grayish-red ledgy slope............

Sandstone, white to moderate orange-pink (5YR 8/4), very fine- to medium-grained, moderately sorted, subangular to subrounded, grains of clear quartz with abundant orange and common black and rare green accessory grains; medium-scale cross-laminations indicated; unit weathers to sandy ledgy slope ................

Claystone, very dusky red $(10 R 2 / 2)$, grayish-purple $(5 P 4 / 2)$ and grayish-red ( $10 R 4 / 2)$; very fine- to medium-grained sandy; sandstone, light greenish-gray $(5 G$ 8/1) mottled grayish-red $(5 R 4 / 2$ ), very fine- to fine-grained, rare medium grains, interstitial clay common, moderately to poorly sorted, subangular to rounded, grains of clear quartz with common orange, red, and black accessory grains; unit weathers to steep earthy slope......

Total Recapture member.

Summerville formation (part):

Claystone and sandstone. Claystone, dark reddish-brown (10R 3/4)

to pale reddish-brown, $(10 R 5 / 4)$ pure to very sandy, very fine- to fine-grained, earthy weathering; sandstone, pale reddish-brown $(10 R 5 / 4)$ to grayish-orange pink (10R 8/2), very fine- to finegrained, moderately sorted, subangular, weak to firm calcareous cement, grains of clear quartz with common black and orange accessory grains; units weathers to earthy slope............ Not measured 


\title{
McKINLEY COUNTY
}

\author{
Haystack Butte section, sec. 13, T. 13 N., R. 11 W.
}

[Measured by L. S. Hilpert and V. L. Freeman, August 1954]

Top of measured section.

Dakota sandstone (part):

Feet

Sandstone, light reddish-orange $(10 R \quad 7 / 6)$, medium-grained, wellsorted, subrounded, grains of quartz with some white chert grains; friable, quartz overgrowths

Shale, carbonaceous. Some interbedded clayey sandstone, grayish-red $(5 R 4 / 2)$, medium-grained, poorly sorted, angular to subrounded.-

Morrison formation:

Brushy Basin member:

Poorly exposed. Local outcrop of claystone, silty and sandy, light greenish-gray ( $5 G Y$ 8/1); and sandstone, pale yellowish-brown (10YR 6/2), medium-grained, poorly sorted, subangular to subrounded, grains of quartz with red and white accessory grains; friable, calcareous cement and specks of white unknown cement_--

Sandstone, slightly conglomeratic, pale yellowish-brown (10YR 6/2) with local greenish-gray ( $5 G Y 6 / 1)$, medium- to coarse-grained, poorly sorted, subangular to subrounded, grains of quartz with red and white accessory grains, granules and pebbles ( $3 / 4 \mathrm{inch})$; friable, calcareous cement and specks of unknown white cement; crossbedding is medium scale and low angle filling shallow erosional troughs.

Claystone, silty and sandy, very dusky red (10R 2/2) and greenishgray $(5 G Y 6 / 1)$

40.0

17.8

67. 2

Sandstone, like second unit below.

Sandstone (at base) and claystone, silty. Sandstone, very pale orange (10YR 8/2), fine-grained, poorly sorted, subrounded, grains of quartz with orange, black, and white accessory grains, possibly some silica cement; claystone, dusky red $(10 R 3 / 2)$.

Sandstone, pale yellowish-brown (10YR 6/2), very coarse-grained at base grading upward to medium-grained at top, poorly sorted, subangular to subrounded, grains of quartz with red and white accessory grains; very friable, calcareous near base, specks ( 1 to $3 \mathrm{~mm}$ açross) of unknown white cement scattered throughout; crossbedding is medium scale and low angle filling shallow erosional troughs.

Claystone, silty, pale reddish-brown $(10 R 5 / 4)$, mottled with yellowish gray $(5 Y 8 / 1)$

Total Brushy Basin member.

Westwater Canyon member:

Sandstone, grayish-red $(10 R 5 / 2)$ to light-brown $(5 Y R 7 / 4)$ in lower part and grayish-orange (10YR 7/2) with some limonite stain near top, poorly sorted, subrounded to rounded, grains of quartz with white, black, and orange accessory grains; locally calcareous in lower part; crossbedding is large scale and low angle filling shallow erosional troughs; mud pods and partings near base; this unit forms a prominent cliff. 
Recapture member:

Feet

Sandstone, very clayey, dark reddish-brown $(10 R 3 / 4)$ and light greenish-gray ( $5 G Y 8 / 1$ ), fine-grained, poorly sorted with some coarse grains, subrounded, grains of quartz with orange, red, and black accessory grains; very calcareous near middle.............

Sandstone, yellowish-gray (5Y 8/1) and light olive-gray (5Y 6/1), finegrained, well-sorted, subrounded, grains of quartz with orange and black accessory grains; slightly calcareous, locally clayey; bedding obscure

Sandstone, very clayey, dark reddish-brown (10R $3 / 4)$ to grayishred $(5 \mathrm{R} 5 / 2)$ with interbeds of pale olive (10Y 6/2) near top, medium-grained, poorly sorted, subrounded, grains of quartz with orange and black accessory grains; calcareous with nodules near top

Sandstone, very light greenish-gray ( $5 G Y 9 / 1)$ to light pinkish-gray (5YR 9/1), fine- to medium-grained, poorly sorted, subrounded, grains of quartz with orange accessory grains; friable, calcareous; bedding obscure

dstone, very clayey, dark reddish-brown $(10 R 3 / 4)$, fine-grained, poorly sorted, subrounded.

Sandstone, light yellowish-gray ( $5 Y 9 / 1)$, medium- to coarse-grained, moderately sorted, subrounded to rounded, grains of quartz with white, orange, and black accessory grains; friable, slightly calcareous; at base are granules and pebbles (1/2 inch) of red, black, and green chert; bedding mostly obscure, some crossbedding is medium scale, low angle, and some is straight in tabular sets....

Sandstone (75 percent) and claystone, sandy. Sandstone, yellowishgray $(5 Y 8 / 1)$ and pinkish-gray $(5 Y R 8 / 1)$, fine-grained, moderately sorted, rounded, grains of quartz with orange and black accessory grains, locally green clay pods in sandstone at base, locally calcareous; claystone, pale yellowish-green (10GY 7/2) with mottling of dark reddish-brown $(10 R 3 / 4) \ldots$

Claystone, sandy, like second unit below, contains some thin sandstone beds near top.

Sandstone, light yellowish-gray (5Y9/1), medium-grained, moderately sorted, subrounded, grains of quartz with orange, red, and black accessory grains; very friable, calcareous especially near top and base; rare scattered pebbles near base; bedding obscure........

Claystone, sandy, mottled dark grayish-red (10R 3/2) and greenishgray $(5 G Y 7 / 1)$, calcareous. Near middle of unit is 8 -inch bed of sandstone, greenish-gray ( $5 G Y 7 / 1)$, very fine grained; friable, calcareous; thin parallel laminations . . . . . . . . . . . . . . . .

Sandstone, pale-red $(10 R 6 / 2)$ and pinkish-gray $(5 Y R 8 / 1)$, mediumgrained with scattered granules and pebbles (1 inch) locally concentrated along laminae; moderately to poorly sorted, rounded; grains of quartz with orange, red, black, and green accessory grains; very friable, calcareous; claystone parting about $7 \frac{1}{2}$ feet above base; bedding mostly parallel but near base is crossbedding of medium to large scale and low angle that fills shallow erosional troughs. .

Total Recapture member ...

Total Morrison formation 
Bluff sandstone:

Sandstone, moderate orange-pink (10R 7/4) to light-brown (5YR 7/4), fine-grained, well-sorted, subrounded, grains of quartz with orange accessory grains; friable, calcareous; crossbedding is large scale and low angle in tabular sets; forms nearly vertical cliff. Not measured

Base of section.

\section{BERNALILLO COUNTY}

North of Cañoncito section, E⿺辶2 sec. 34, T. 11 N., R. 3 W.

[Measured by V. L. Freeman, October 1954]

Top of section.

Dakota sandstone:

Not measured or described.

Morrison formation:

Brushy Basin member:

Claystone, sandy, light greenish-gray (5G 8/1), minor amounts of sandstone and limy nodules, forms frothy surface. Poorly exposed, especially near top.

Sandstone, yellowish-gray (5Y 8/1), medium-grairted; moderately sorted, subrounded, grains of clay coated quartz with orange, black, and white accessory grains, quartz, clay, and calcite cement; bedding indistinct but in part is crossbedded on medium

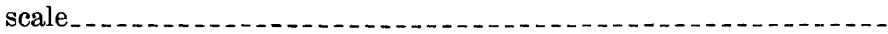

Claystone, sandy, and sandstone, clayey, yellowish-gray $(5 Y 8 / 1)$ to light brownish-gray (5YR 6/1) with minor greenish tint; some limy nodules and chert; forms slightly frothy surface ............

Total Brushy Basin member

Gradational contact

Recapture member (probably includes equivalents to Westwater Canyon member):

Sandstone, partly clayey, yellowish-gray ( $5 Y$ 8/1) with limonite stains near base, fine- to medium-grained, moderately sorted; friable, calcareous especially near base; bedding not visible...........

Claystone, very sandy (to medium-grained), grayish-red (10R 4/2), calcareous. Unit contains one thin hard green sandstone bed; forms slightly frothy surface

Sandstone, moderate orange-pink $(5 Y R 8 / 4)$ to yellowish-gray (5Y $8 / 1$, medium-grained, poorly sorted, rounded, grains of quartz with uncommon black and orange accessory grains; friable, calcareous cement and uncommon specks of unknown white cement; crossbedding is small to medium scale

Claystone, very sandy and sandstone, clayey; grayish-red (10R 4/2), calcareous; sandstone in thin irregular beds totaling about half of unit

Sandstone, yellowish-gray (5Y 8/1), medium-grained, moderately sorted, rounded, grains of quartz with common black, orange, red, and white accessory grains; alternating hard and friable

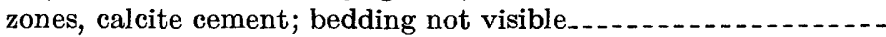

Claystone, very sandy, like second unit below. 
Recapture member-Continued

Sandstone, yellowish-gray (5Y 8/1), fine-grained, poorly sorted, rounded, grains of quartz with uncommon orange, red, black, and white accessory grains; slightly friable, calcareous; structureless; common limonite staining. Unit grades into unit above...

Claystone, very sandy (to medium-grained), grayish-red $(10 R 4 / 2)$, calcareous, several irregular thin beds of sandstone.........

Total Recapture member and probable equivalents of Westwater Canyon member

Total Morrison formation

Bluff sandstone (part):

Sandstone, grayish-yellow ( $5 Y 7 / 4)$, fine-grained, well-sorted, rounded, grains of quartz with black, white, and orange accessory grains; friable; bedding indistinct but in part is extremely large-scale Base of section.

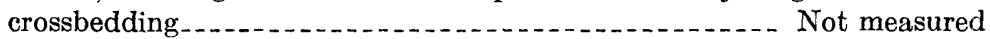

Red Bluff section, W1/2 sec. 3, T. 12 N., R. 9 W.

[Measured by V. L. Freeman and L. S. Hilpert, August 1954]

Top of measured section.

Dakota sandstone (part):

Feet

Sandstone, very pale orange $(10 Y R \quad 8 / 2)$, to dark yellowish-orange (10YR 6/6), the yellow coloring caused by limonite staining generally along bedding, medium-grained, poorly sorted with local scattered granules and pebbles of red and black chert and vein quartz, subangular to rounded, grains of quartz with rare chert and white accessory grains; abundant quartz overgrowths; parallel bedded with some tabular crossbedding ... . . . . . . . . .

Morrison formation:

Brushy Basin member:

Claystone and sandstone, clayey, poorly exposed; greenish-gray $(5 G Y 6 / 1)$ at base and pale-olive $(10 Y 6 / 2)$; local calcareous thinbedded sandstone lenses, greenish-gray $(5 G Y 6 / 1)$, fine-grained.-

Sandstone, pale yellowish-brown (10YR 7/2), medium- to coarsegrained, poorly sorted with local granules and small pebbles, subangular to rounded, grains of quartz with uncommon orange and black accessory grains; crystal calcite cement at top and specks of unknown white cement throughout; cross-laminations are medium scale and low angle filling shallow erosion troughs

Mostly covered; some claystone, yellowish-gray (5Y 8/1) and light greenish-gray ( $5 G Y 8 / 1$ ), free of sand grains, some limy nodules, some seams of gypsum . .

Sandstone, yellowish-gray ( $5 Y 8 / 1)$, medium-grained, poorly sorted, rounded, grains of quartz with white, black, green, and orange accessory grains; friable, calcareous; forms surface coated by small nodules.

88. 0

Claystone, slightly sandy, grayish-yellow green $(5 G Y 7 / 2)$ and light grayish-red $(10 R 5 / 2)$ in lower part, common limy nodules....

Total Brush Basin member 
Westwater Canyon member:

Sandstone, grayish-orange $(10 Y R \quad 7 / 4)$ with widespread limonite specks, medium- to coarse-grained, moderately to poorly sorted with scattered granules, subrounded, grains of quartz with common white (kaolin?) and rare black (chert?) accessory grains; friable, local crystal calcite cement; cross laminations are medium scale and low angle between planar erosion surfaces. Locally claystone, pale yellowish-green $(10 G Y 7 / 2)$ occurs near the base in irregular pods

Total Westwater Canyon member.

62. 2

Recapture member:

Sandstone, clayey, and some claystone, sandy, dusky red-purple $(5 R P 3 / 2)$ and greenish-gray (5GY 6/1), sandstone is fine grained, claystone locally contains limy nodules; unit forms mostly covered slope

Sandstone, light yellowish-gray ( $5 Y 9 / 1)$, fine- to coarse-grained, local conglomeratic lenses with pebbles dominantly of chert, moderately to poorly sorted, subrounded, grains of quartz with white, orange, and black accessory grains; crystal calcite cement; crossbedding filling scours . . . . . . . .

Sandstone, clayey, and claystone, sandy. Claystone mostly light greenish-gray (5GY 8/1) and brownish-gray (5YR 4/1) with some grayish-red purple (5RP 4/2) and dusky yellow (5Y 6/4); sandstone is fine grained and poorly sorted; local limy nodules.........

Sandstone, light yellowish-gray (5Y 9/1), medium-grained, poorly sorted, rounded, grains of quartz with white and orange accessory grains, scattered granules and green clay chips; friable, locally calcareous; bedding obscure; weathers to rounded ledge.......-

Sandstone, clayey, very dusky red purple (5RP 2/2), very fine- to fine-grained, moderately sorted, grains of quartz with black and orange accessory grains; local small limy nodules. Unit contains local thin beds of sandstone, greenish-gray (10GY 5/2); hard, clay cement.

Sandstone, light yellowish-gray (5Y 9/1) and very light greenish.gray (5GY 9/1), fine- to medium-grained, poorly sorted, subrounded, grains of quartz with white, orange, red, green, and black accessory grains; friable; crossbedding is small to medium scale and low angle in tabular sets between planar erosion surfaces......-

Sandstone, lenticular with thin irregular lenses and pods of claystone; claystone, dark reddish-brown (10R 3/4) mottled light greenishgray (5GY 8/1); sandstone, light pinkish-gray ( $5 Y R 9 / 1)$, mediumto coarse-grained with scattered granules, poorly sorted, subrounded to rounded, grains of quartz with orange and black accessory grains; friable, calcareous; crossbedding is small scale and low angle in wedge-shaped sets

Sandstone, light pinkish-gray ( $5 Y R 9 / 1$ ), medium- to coarse-grained with rare granules, poorly sorted, subrounded to rounded, grains of quartz and chert with white and orange accessory grains; friable; in part is parallel bedded and in part is crossbedded, medium scale, low angle. This unit fills a channel in underlying unit that is 2 to 4 feet deep and about 20 feet wide 
Recapture member-Continued

Sandstone, slightly clayey, greenish-gray ( $5 G Y 6 / 1$ ), medium-grained, moderately sorted, rounded, grains of quartz with uncommon orange and red and rare black accessory grains; forms slope.....

Claystone, slightly silty, very dusky red $(10 R 2 / 3)$; some limy nodules and gypsum; forms rounded slope

Sandstone, slightly clayey, pale olive $(10 Y$ 6/2) with some limonite stains, fine- to medium-grained, moderately sorted, rounded, grains of quartz plus common orange and rare black accessory grains; very friable; forms slope. Unit appears gradational with Bluff sandstone. . . . . . . . .

Total Recapture member.

Total Morrison formation

Bluff sandstone (part) :

Sandstone, grayish-yellow ( $5 Y 8 / 4$ ), fine- to medium-grained; very friable, calcareous concretions locally present; cross-laminations are medium to large scale and high angle in wedge-shaped sets_. - Not

measured

Base of section.

\section{VALENCIA COUNTY}

Sheep Camp section, S1 12 sec. 2, T. 8 N., R. $6 \mathrm{~W}$.

[Measured by V. L. Freeman, September 1954]

Top of measured section.

Dakota sandstone (part):

Sandstone, like basal Dakota unit, two silicified 6-inch bands, also a few

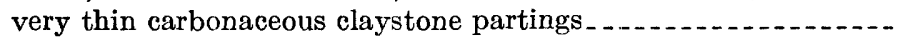

Claystone, carbonaceous, sandy. Along strike, unit becomes sandstone like below with very thin partings of carbonaceous claystone. Unit forms reentrant in cliff.

Sandstone, light-yellow (5Y 8/6), medium-grained, poorly sorted, granules common, rounded, grains of clay-coated quartz with white (chert?) accessory grains; one 6-inch band is highly silicified and white; very thin crossbedding is medium scale and low angle.

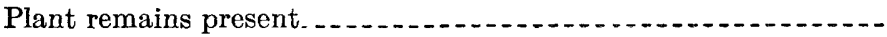

\section{Morrison formation:}

Claystone, slightly fine-grained sandy, pale-olive (10Y6/2) and minor grayish-red purple; forms slightly frothy surface.

Sandstone, white (N9), medium-grained, well to moderately sorted, subrounded, grains of quartz with orange and white accessory grains; slightly friable, calcareous cement; indistinct crossbedding is medium scale and low angle.

Claysfone, like second unit below with two thin. beds of sandstone, like below, that total 3 feet

Sandstone, white $(N 9)$, medium-grained, well to moderately sorted, subrounded, grains of quartz with orange and white accessory grains; slightly friable, calcareous cement; indistinct crossbedding is medium scale and low angle

Claystone, slightly fine-grained sandy, pale-olive (10Y6/2) and minor grayish-red purple $(5 R P 4 / 2)$; forms slightly frothy surface.... 
Morrison formation-Continued

Sandstone, very light greenish gray ( $5 G Y$ 8/1), fine- to mediumgrained, well- to moderately sorted, subrounded, grains of quartz with orange and white accessory grains; slightly friable, calcareous cement; crossbedding is medium seale and low angle. Uncommon limy nodules. Unit is lenticular and interfingers with unit above.

Sandstone, clayey, very dusky red (between $5 R P 2 / 2$ and $10 R 2 / 2$ ) and light greenish-gray $(5 G Y 8 / 1)$ in about equal amounts in alternating bands, medium-grained, moderately sorted, subrounded, grains of quartz and rare orange accessory grains; hard when fresh; unit forms soft slope. Laterally unit contains lens like unit above

16.8

Sandstone, clayey, dark reddish-brown (10R 3/5), fine-grained, moderately sorted, subrounded, grains of stained quartz with rare black accessory grains; hard when fresh; unit forms soft slope. Unit grades into Bluff sandstone and locally interfingers with Bluff

8. 5

Note.-Lower two units of Morrison probably are equivalent to Recapture member and remainder probably equivalent to Brushy Basin member.

Total Morrison formation.

Bluff sandstone (part):

Sandstone, light greenish-yellow (10Y 7/2) slightly lighter near top, medium- and fine-grained in gradationally alternating 6-inch beds, well sorted to moderately sorted, subrounded to rounded, grains of green clay coated quartz with common white chert and rare orange accessory grains; friable, zones of heavy limonite cement. Poorly defined parallel bedding underlain by crossbedding of Base of section. extremely large scale and low angle............ Not measured

\section{VALENCIA COUNTY}

\section{West Mesa Gigante section (composite)}

[Measured by V. L. Freeman, September, October 1954]

Top of section.

Section A., sec. 10, T. 10 N., R. 4 W.

Dakota sandstone:

Not measured. Sandstone, conglomeratic, with minor carbonaceous shale. Siliceous cement.

Morrison formation:

Brushy Basin member:

Sandstone, yellowish-gray (5Y 8/1) to white (N9), medium-grained, well to poorly sorted, subrounded to subangular, grains of clay coated quartz with rare pink and black accessory grains, green clay chips locally abundant but usually rare; friable, some calcareous cement and specks of white unknown cement; crossbedding is medium scale and low angle filling shallow erosion troughs. This is the Jackpile ore-bearing bed.............

Claystone, silty, and siltstone, clayey, light greenish-gray (5GY 8/1) and minor grayish-red $(10 R 4 / 2)$, limy nodules common. Near top is 2-foot bed of sandstone, clayey, light grayish-green (5GY 6/2) . . . 
Brushy Basin member-Continued

Sandstone, yellowish-gray (5Y 8/1), medium-grained, poorly sorted, subrounded to subangular, grains of clay coated quartz with orange, red, black, and rare green accessory grains; granules and pebbles ( $1 / 2$ inch) scattered in sandstone, include feldspar; crossbedding is medium scale and low angle, filling shallow erosion troughs.

20. 0

Claystone, silty; siltstone and very fine sandstone, both very clayey; all light greenish gray $(5 G 8 / 1)$, some hard calcareous beds, weathers to frothy surface

Sandstone, very pale orange $(10 Y R 8 / 2)$ to dark yellowish-brown $(10 Y R 3 / 4)$, medium-grained, moderately sorted, grains of quartz with green, orange, red, and black accessory grains; hard; crossbedding is medium scale and low angle. Three beds with clay chips at base of each .

Siltstone and very fine sandstone; both clayey, pinkish-gray (5YR 8/1) and light greenish-gray ( $5 G Y 8 / 1)$, calcareous; also claystone, silty, light greenish-gray $(5 G Y 8 / 1)$ and minor pale-purple $(5 P 6 / 2)$, hard, calcareous; some units weather to frothy surface.

Total Brushy Basin member.

Section B, SW1/4 sec. 23, T. 10 N., R. 4 W.

Morrison formation-Continued

Westwater Canyon member:

Sandstone, very pale orange $(10 Y R 8 / 2)$ to dusky yellow $(5 Y 6 / 4)$, medium- to coarse-grained, poorly to moderately sorted, subrounded to angular, grains of quartz and feldspar (angular and as much as granules in size) with common red and white (chert?) accessory grains; some beds clayey; friable except for local crystal calcite cement. Indistinct crossbedding ............

Sandstone, like purple part of third unit below

Sandstone (75 percent) and claystone with limy nodules (25). Sandstone, very pale orange $(10 Y R 8 / 2)$, medium- to coarse-grained, moderately sorted, rounded to subrounded, grains of quartz and feldspar with common red and white and uncommon green and gray accessory grains; friable, calcareous, locally crystal calcite cement; crossbedding is small to medium scale, low angle, lenticular type; claystone like below but pale purple $(5 P 7 / 2)$ and with large ( 1 foot) nodules that form bed

Total Westwater Canyon member

Note.-On section A where base is not exposed, the incomplete Westwater Canyon is 62 feet thick.

Recapture member:

Claystone, slightly fine-grained sandy, light greenish-gray (5G 8/1) with purplish tints locally, limy nodular beds total 2.0 feet. Claystone is slightly calcareous

Sandstone, very clayey, pale yellowish-green $(10 G Y 7 / 2)$ in middle third, rest is grayish red-purple $(5 R P 4 / 2)$. Medium-grained, poorly sorted, rounded, grains of quartz with common orange and red and rare black and white accessory grains. Purple part is calcareous. Bedding obscure 


\section{4}

Recapture member-Continued

Claystone, very sandy (fine-grained) (50 percent) and sandstone (50 percent). Claystone, reddish-brown (10R 4/4), slightly calcareous but not containing limy nodules here; sandstone, yellowish gray, mediumgrained, moderately sorted, rounded, grains of quartz with uncommon orange, black, and red accessory grains; bedding obscure. Sandstone and claystone thickly (2 to 3 feet) interbedded. Claystone beds weather to slightly frothy surface.

Total Recapture member

Total Morrison formation

470. 3

Bluff sandstone (part):

Sandstone, grayish-yellow (5Y 8/4) to moderate yellow $(5 Y 7 / 6)$, medium-grained, well to moderately sorted, rounded grains of quartz with black, orange, and white accessory grains; friable, local crystal calcite cement. Crossbedding is large scale and poorly defined.

Not measured

Base of section. 




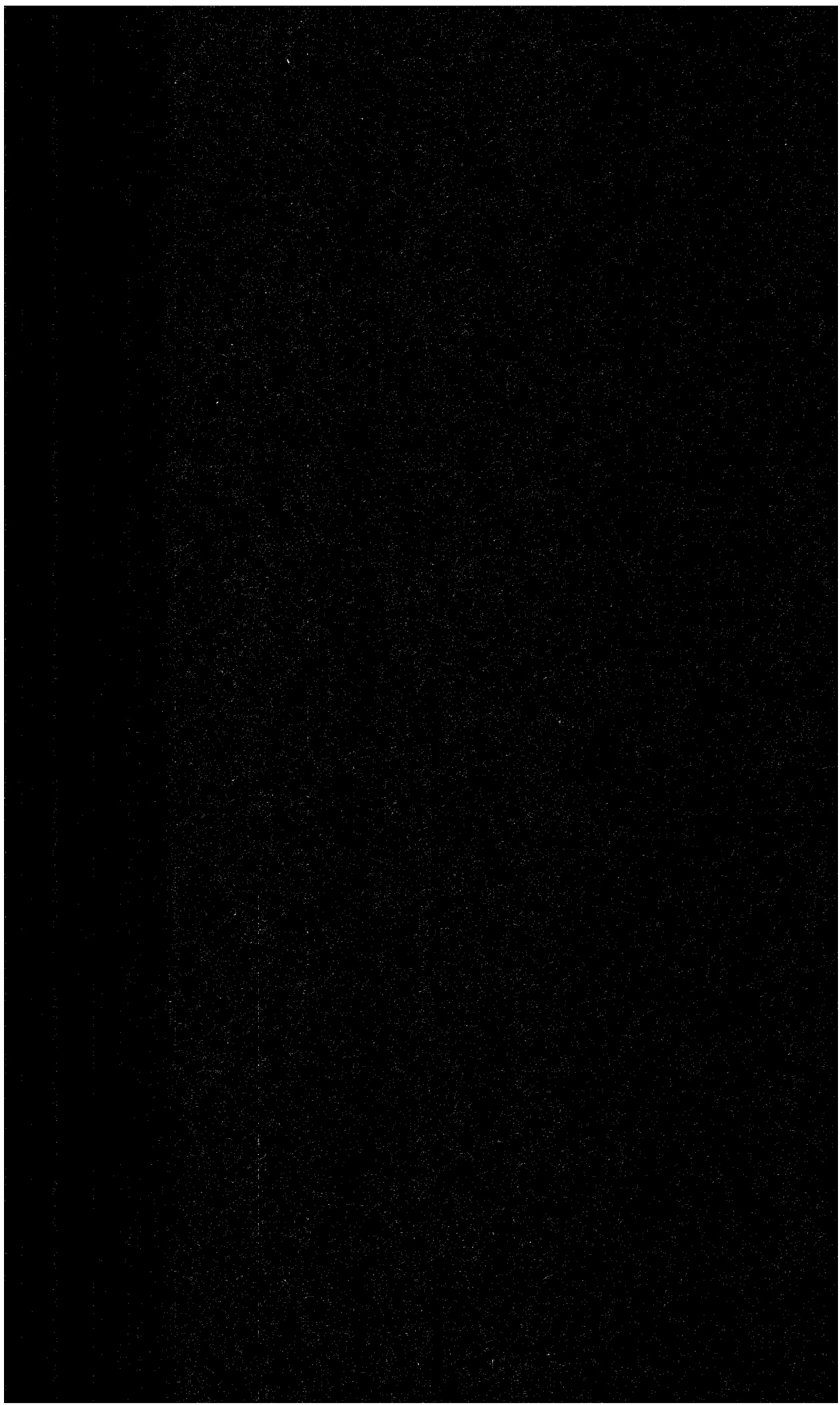




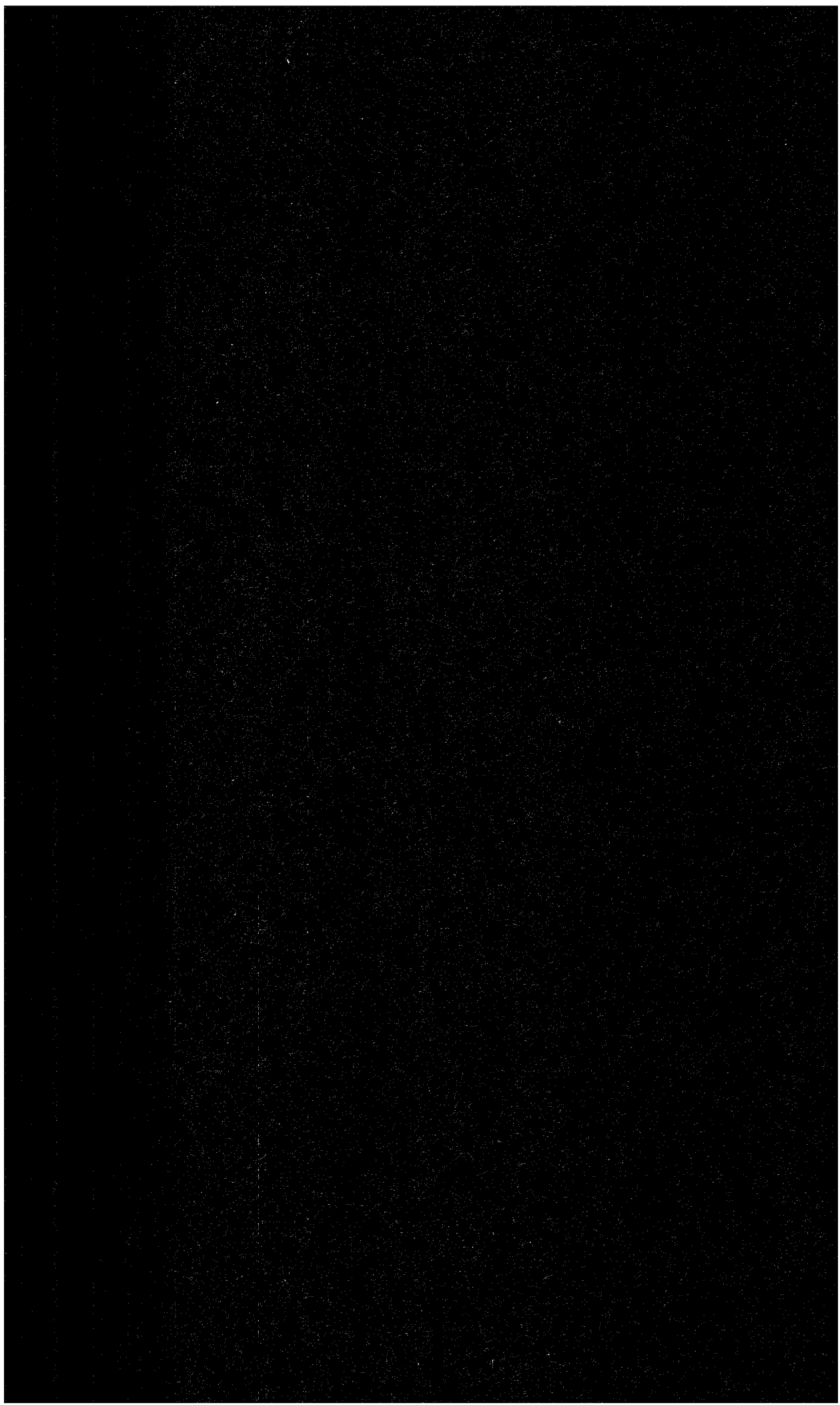

